\title{
Detection of $t(11 ; 14)$ Using Interphase Molecular Cytogenetics in Mantle Cell Lymphoma and Atypical Chronic Lymphocytic Leukemia
}

\author{
Hervé Avet-Loiseau, ${ }^{1 *}$ Richard Garand, ${ }^{1}$ Fanny Gaillard, ${ }^{2}$ Axelle Daviet, ${ }^{1}$ Marie-Paule Mellerin, ${ }^{1}$ Nelly Robillard, ${ }^{1}$ \\ Isabelle Bouyge, ${ }^{3}$ Santosh Arcot, ${ }^{4}$ Mark Batzer, ${ }^{5}$ Pascaline Talmant, ${ }^{1}$ Jean-Luc Harousseau, ${ }^{6}$ Noël Milpied, ${ }^{6}$ \\ and Régis Bataille \\ ${ }^{1}$ Labo ratory of $\mathrm{H}$ ematology, U niversity Hospital, $\mathrm{N}$ antes, France \\ 2Laboratory of Pathology, U niversity H ospital, $\mathrm{N}$ antes, France \\ 3 IN SERM U 463, N antes, France \\ ${ }^{4}$ Human Genome Center, Lawrence Livermore N ational Laboratory, Livermore, California \\ ${ }^{5}$ Department of Pathology, Stanley Scott Cancer Center, N ew O rleans, Louisiana \\ ${ }^{6}$ Department of $\mathrm{C}$ linical $\mathrm{H}$ ematology, University Hospital, $\mathrm{N}$ antes, France
}

The chromosomal translocation $\mathrm{t}(11 ; 14)(q 13 ; q 32)$ fuses the IGH and CCND1 genes and leads to cyclin D 1 overexpression. This genetic abnormality is the hallmark of mantle cell lymphoma $(M C L)$, but is also found in some cases of atypical chronic lymphocytic leukemia (CLL), characterized by a poor outcome. For an unequivocal assessment of this specific chromosomal rearrangement on interphase cells, we developed a set of probes for fluorescence in situ hybridization (FISH). Northern blotting was performed for analysis of the cyclin D 1 expression in 18 patients. Thirty-eight patients, with either a typical MCL leukemic phase (17 patients) or atypical CLL with an MCL-type immunophenotype, i.e., CD 19+, CD 5+, CD 23-/low, CD 79b/ $\operatorname{slgM}(D)^{++}$, and FMC 7+ (21 patients), were analyzed by dual-color interphase FISH. W e selected an IGH-specific BAC probe (covering the $\mathrm{JH}$ and first constant regions) and a commercially available CCND1 probe. An IGH-CCND1 fusion was detected in 28 of the 38 patients (17 typical MCL and 11 cases with CLL). C yclin D 1 was not overexpressed in two patients with typical $M C L$ and an IGH-CCND1 fusion. In view of the poor prognosis associated with MCL and t(11;14)-positive CLL, we conclude that this set of probes is a valuable and reliable tool for a rapid diagnosis of these entities. Genes Chromosomes Cancer 23:175-182, 1998. @ 1998 W iley-Liss, Inc.

\section{INTRODUCTION}

Mantle cell lymphoma (MCL) is a non-Hodgkin's lymphoma (NHL) that was recently recognized as a specific entity in the revised NHL classification (Harris et al., 1994). The accuracy of this individualization is confirmed by clinical studies, all of which demonstrate the poor outcome of MCL patients (Coiffier et al., 1995; Fisher et al., 1995; Stewart et al., 1995; Teodorovic et al., 1995; Zucca et al., 1995). The normal counterpart of these malignant cells is well characterized (naive B-cells that home to and reside in primary lymphoid follicles and the mantle zones of secondary follicles). However, identification of malignant lymphocytes such as MCL cells may be a difficult challenge for pathologists. Although different immunologic, cytogenetic, and molecular characteristics may be useful for recognizing these malignant lymphocytes, none of them is constant and specific. Leukemic phases are frequent and may be inaugural in MCL. It may be difficult to distinguish the morphology of circulating abnormal cells in MCL from those in atypical chronic lymphocytic leukemia (CLL). Flow studies cannot always differentiate between these cell types. Like CLL cells, MCL cells coexpress the T-cell antigen CD5, panB antigens (CD19, CD20, and CD22), and surface IgM (and usually IgD). In contrast, FMC7 positivity, strong expression of B-cell receptor CD79b/sIg molecules, and weak expression of CD23 (or none) are specific for MCL cells (Lardelli et al., 1990; Matutes et al., 1994; Segal et al., 1995; Garand and Robillard, 1996; Weisenburger and Armitage, 1996). However, this typical MCL immunophenotypic profile may be encountered in some cases of typical CLL (Garand and Robillard, 1996).

Cytogenetic analyses in MCL usually show a $\mathrm{t}(11 ; 14)(\mathrm{q} 13 ; \mathrm{q} 32)$, but approximately $40 \%$ of analyzed cases apparently lack this typical translocation (Leroux et al., 1991; Vandenberghe et al., 1992). On chromosome 14, breakpoints occur within the Ig heavy chain $(I G H)$ gene, usually in the $J H$

*Correspondence to: Dr. Hervé Avet-Loiseau, Unité de Cytogénétique Hématologique, Institut de Biologie, 9 quai Moncousu, 44093 Nantes Cédex, France.

Received 22 September 1997; Accepted 5 June 1998

1998 W iley-Liss, Inc. 
region. On chromosome 11, breakpoints are not tightly clustered, but occur over at least $130 \mathrm{~kb}$ upstream of the CCND1 gene, which encodes the cyclin D1 protein (de Boer et al., 1993, 1995a, 1995b; Rimokh et al., 1993). Because of the dispersed 11q13 breakpoints, molecular studies (Southern blot or PCR experiments) fail to detect the rearrangements in $30-50 \%$ of cases (de Boer et al., 1993; Rimokh et al., 1994; Luthra et al., 1995). Theoretically, the best diagnostic test is the demonstration of cyclin D1 overexpression by use of Northern blotting (de Boer et al., 1993; Rimokh et al., 1993). However, this test is time-consuming and usually is not performed in routine analysis. Recently, a new competitive RT-PCR-based approach has been reported (Uchimaru et al., 1997). Despite encouraging results, this technique needs to be evaluated on a larger series of patients, which, unfortunately, is usually not available in routine laboratories.

In order to circumvent the lack of sensitivity of molecular techniques, we have developed a fluorescence in situ hybridization (FISH) approach to detect the IGH-CGND1 rearrangements on interphase nuclei. After selection of adequate $14 \mathrm{q} 32$ and $11 \mathrm{q} 13$ probes, we have analyzed 38 patients with either a leukemic phase of MCL or an atypical CLL with an MCL-type immunophenotype.

\section{MATERIALS AND METHODS}

\section{Patients}

Seventeen patients with a histologic diagnosis of MCL according to the REAL classification (Harris et al., 1994) and a leukemic phase were selected for this study. We also analyzed 21 patients cytologically diagnosed as atypical CLL (20 cases with mixed-cell-type CLL and one patient with Bprolymphocytic leukemia) (Bennett et al., 1989), but with an immunophenotype characteristic of MCL (i.e., CD19 ${ }^{+}, \mathrm{CD}^{+}, \mathrm{CD}^{2} 3^{-/ \text {low }}$, CD79b/ $\left.\operatorname{sIgM}(\mathrm{D})^{++}, \mathrm{FMC7}^{+}\right)($Matutes et al., 1994; Garand and Robillard, 1996). Their clinical, morphologic, immunologic, and molecular characteristics are summarized in Tables 1 and 2. For 34 of these patients, analyses were performed on frozen bone marrow (2 cases) or peripheral blood (32 cases) samples. In two cases, we analyzed PB cytospins. In two other patients, we used BM cytogenetic preparations.

\section{Immunologic Analyses}

Peripheral blood $(\mathrm{n}=35)$ or bone marrow $(\mathrm{n}=3)$ mononuclear cells were isolated using FicollHypaque and analyzed by dual-color fluorescence
TABLE 1. Main Clinical, H istocytologic, Molecular, and Immuno logic $\mathrm{C}$ haracteristics

\begin{tabular}{|c|c|c|c|c|c|}
\hline Patients & Sex & $\begin{array}{l}\text { Age } \\
\text { (year) }\end{array}$ & $\begin{array}{c}\text { Clinical } \\
\text { involvementa }\end{array}$ & Cytology ${ }^{b}$ & Histologyc \\
\hline 1 & $\mathrm{~F}$ & 57 & $A D P, S M G$ & PL & MCL \\
\hline 2 & M & 42 & $\begin{array}{l}\text { ADP, SMG, } \\
\text { DT }\end{array}$ & PL & $M C L$ \\
\hline 3 & $\mathrm{~F}$ & 74 & $A D P, S M G$ & $\mathrm{Pl}$ & MCL \\
\hline 4 & M & 59 & SMG & $P L+P L Y$ & MCL "BL" \\
\hline 5 & M & 66 & $A D P, S M G$ & PL & $M C L$ \\
\hline 6 & M & 87 & ADP & $P L+P L Y$ & MCL \\
\hline 7 & $\mathrm{~F}$ & 41 & $A D P, S M G$ & $P L+P L Y$ & MOL \\
\hline 8 & $\mathrm{~F}$ & 73 & $\begin{array}{l}\text { ADP, SMG, } \\
\text { liver }\end{array}$ & "Blastoid" & ND \\
\hline 9 & $\mathrm{~F}$ & 73 & $A D P, S M G$ & $\mathrm{PL}$ & $M C L$ \\
\hline 10 & $\mathrm{~F}$ & 43 & $\begin{array}{l}\text { ADP, SMG, } \\
\text { liver, thy- } \\
\text { roid }\end{array}$ & PL & $M C L$ \\
\hline 11 & M & 57 & $A D P, S M G$ & $P L+P L Y$ & MCL "BL" \\
\hline 12 & M & 71 & $A D P, S M G$ & $P L+P L Y$ & $\mathrm{MCL}$ \\
\hline 13 & M & 57 & ADP, SMG & PL & $M C L$ \\
\hline 14 & M & 51 & $\begin{array}{l}\text { ADP, SMG, } \\
\text { skin }\end{array}$ & PL & LPL \\
\hline 15 & $\mathrm{~F}$ & 48 & $\begin{array}{l}\text { ADP, SMG, } \\
\text { liver }\end{array}$ & SL & $M C L$ \\
\hline 16 & $\mathrm{~F}$ & 66 & $A D P$, skin & $P L+P L Y$ & $M C L$ \\
\hline 17 & $\mathrm{~F}$ & 71 & $\begin{array}{l}\text { ADP, SMG, } \\
\text { liver }\end{array}$ & "Blastoid" & MCL "BL" \\
\hline 18 & $\mathrm{~F}$ & 85 & None & PL & ND \\
\hline 19 & M & 69 & None & $\mathrm{PL}+\mathrm{PLY}$ & ND \\
\hline 20 & M & 69 & SMG, liver & $P L+P L Y$ & ND \\
\hline 21 & $M$ & 72 & $\mathrm{SMG}$ & $P L+P L Y$ & LPL \\
\hline 22 & $F$ & 94 & $\begin{array}{l}\text { SMG, DT, } \\
\text { CNS }\end{array}$ & PL & ND \\
\hline 23 & M & 67 & $\begin{array}{l}\text { ADP, SMG } \\
\text { liver }\end{array}$ & PL & LPL \\
\hline 24 & $\mathrm{~F}$ & 75 & SMG & $P L+P L Y$ & SLL \\
\hline 25 & M & 73 & SMG & $\mathrm{PL}$ & ND \\
\hline 26 & $\mathrm{~F}$ & 82 & None & PL & SLL \\
\hline 27 & M & 55 & $A D P, S M G$ & PLY & PLL \\
\hline 28 & M & 51 & $\mathrm{SMG}$ & $P L+P L Y$ & ND \\
\hline 29 & M & 66 & SMG & $P L+P L Y$ & ND \\
\hline 30 & M & 72 & $A D P, S M G$ & $\mathrm{PL}$ & ND \\
\hline 31 & M & 77 & SMG & PL & ND \\
\hline 32 & $\mathrm{~F}$ & 67 & None & $\mathrm{PL}$ & ND \\
\hline 33 & $\mathrm{~F}$ & 56 & $A D P, S M G$ & $\mathrm{PL}$ & $M C L$ \\
\hline 34 & M & 74 & SMG, liver & SL & ND \\
\hline 35 & M & 69 & $A D P, S M G$ & $\mathrm{PL}$ & MCL "BL" \\
\hline 36 & M & 83 & $A D P, S M G$ & $\mathrm{PL}$ & ND \\
\hline 37 & $\mathrm{~F}$ & 84 & None & $\mathrm{PL}$ & ND \\
\hline 38 & $\mathrm{~F}$ & 54 & None & $\mathrm{PL}$ & ND \\
\hline
\end{tabular}

${ }^{a} A D P=$ adenopathy; SMG = splenomegaly; $D T$ = digestive tract; $\mathrm{CNS}=$ central nervous system.

${ }^{\mathrm{b} P L}=$ pleiomorphic lymphocytes; PLY = prolymphocytes; SL = small monomorphic lymphocytes.

${ }^{\mathrm{CND}}=$ not done; $\mathrm{LPL}=$ lymphoplasmacytic lymphoma; $\mathrm{PLL}=$ prolymphocytic leukemia; SLL = small lymphocytic lymphoma; $\mathrm{MCL}=$ mantle cell lymphoma; "BL" = blastoid variant.

flow cytometry (FACSCALIBUR, Beckton-Dickinson). Different combinations of monoclonal antibodies-directly labeled with fluorescein isothiocya- 
TABLE 2. Immunologic and FISH Characteristics

\begin{tabular}{|c|c|c|c|c|c|c|}
\hline Patients & Phenotype $^{a}$ & $\begin{array}{c}\% \\
\text { B-cellsb }\end{array}$ & $\begin{array}{c}\% \text { CD } 5+ \\
\text { B-cells }\end{array}$ & $\begin{array}{c}\text { Cyto genetics }(C) \text {, } \\
\text { So uthern }(S) \text {, and } \\
\text { N orthern }(N)^{c}\end{array}$ & $\begin{array}{c}\text { FISH }^{d} \\
\text { (configuration) }\end{array}$ & $\begin{array}{c}\% \text { Cells } \\
\text { with fusion }\end{array}$ \\
\hline 1 & $A(\lg D-)$ & 64 & 48 & ND & $R(A)$ & 62 \\
\hline 2 & $\mathrm{C}$ & 73 & 73 & $\mathrm{C}-, \mathrm{N}+, \mathrm{S}+$ & $R(A)$ & 65 \\
\hline 3 & $\mathrm{C}$ & 92 & 77 & ND & $R(B)$ & 94 \\
\hline 4 & $\mathrm{C}$ & 87 & 85 & $\mathrm{~N}-$ & $R(A)$ & 85 \\
\hline 5 & $A(C D 5-)$ & 97 & 0 & $\mathrm{~S}+$ & $R(A)$ & 93 \\
\hline 6 & $\mathrm{C}$ & 74 & 74 & ND & $R(A)$ & 80 \\
\hline 7 & $\mathrm{C}$ & 90 & 90 & $\mathrm{C}+, \mathrm{N}+, \mathrm{S}-$ & $R(B)$ & 90 \\
\hline 8 & $A(\lg D-)$ & 97 & 91 & $\mathrm{C}+, \mathrm{S}-$ & $R(A)$ & 83 \\
\hline 9 & $\mathrm{C}$ & 88 & 88 & ND & $R(A)$ & 79 \\
\hline 10 & $\mathrm{C}$ & 75 & 75 & $\mathrm{~N}+$ & $R(A)$ & 68 \\
\hline 11 & $\mathrm{C}$ & 61 & 57 & $\mathrm{~N}+$ & $R(B)$ & 60 \\
\hline 12 & $\mathrm{C}$ & 85 & 85 & $\mathrm{~N}-$ & $R(A)$ & 82 \\
\hline 13 & $\mathrm{C}$ & 78 & 76 & ND & $R(A)$ & 70 \\
\hline 14 & $\mathrm{C}$ & 55 & 43 & ND & $R(A)$ & 51 \\
\hline 15 & $\mathrm{C}$ & 65 & 61 & $\mathrm{~N}+$ & $R(A)$ & 60 \\
\hline 16 & $\mathrm{C}$ & 79 & 79 & ND & $R(A)$ & 75 \\
\hline 17 & $\mathrm{C}$ & 79 & 78 & $\mathrm{~N}+, \mathrm{S}+$ & $R(A)$ & 80 \\
\hline 18 & $\mathrm{C}$ & 78 & 75 & $\mathrm{~N}+$ & $R(A)$ & 73 \\
\hline 19 & $\mathrm{C}$ & 50 & 48 & $\mathrm{~N}+$ & $R(A)$ & 45 \\
\hline 20 & C & 89 & 89 & $\mathrm{~N}+$ & $R(A)$ & 91 \\
\hline 21 & $\mathrm{C}$ & 77 & 69 & $\mathrm{~N}-, \mathrm{S}-$ & NR & 2 \\
\hline 22 & $\mathrm{C}$ & 73 & 72 & $\mathrm{~N}+$ & $R(A)$ & 70 \\
\hline 23 & $\mathrm{C}$ & 64 & 55 & $\mathrm{~N}-$ & NR & 1 \\
\hline 24 & $\mathrm{C}$ & 86 & 31 & ND & NR & 3 \\
\hline 25 & $A(\lg D-)$ & 88 & 88 & ND & NR & 2 \\
\hline 26 & $C$ & 93 & 82 & $\mathrm{~N}-$ & NR & 2 \\
\hline 27 & $A(\lg D-)$ & 88 & 88 & $\mathrm{~N}-$ & NR & 3 \\
\hline 28 & C & 73 & 50 & $\mathrm{~N}-$ & NR & 1 \\
\hline 29 & $\mathrm{C}$ & 86 & 84 & $\mathrm{~N}+$ & $R(A)$ & 81 \\
\hline 30 & $\mathrm{C}$ & 83 & 78 & ND & $R(A)$ & 92 \\
\hline 31 & $\mathrm{C}$ & 55 & 55 & ND & $R(A)$ & 54 \\
\hline 32 & $\mathrm{C}$ & 82 & 31 & ND & NR & 1 \\
\hline 33 & $\mathrm{C}$ & 71 & 70 & ND & $R(A)$ & 63 \\
\hline 34 & $A(\lg D-)$ & 79 & 71 & ND & $R(A)$ & 84 \\
\hline 35 & C & 73 & 70 & ND & $R(A)$ & 68 \\
\hline 36 & $A(\lg D-)$ & 66 & 66 & ND & $R(A)$ & 60 \\
\hline 37 & $\mathrm{C}$ & 41 & 41 & ND & NR & 2 \\
\hline 38 & $\mathrm{C}$ & 84 & 84 & ND & NR & 2 \\
\hline
\end{tabular}

${ }^{\mathrm{a}} \mathrm{C}=$ common $\left(\mathrm{CD} \mathrm{19} 9^{+}, \mathrm{CD}^{+}, \mathrm{CD} 23^{-110 \mathrm{w}}, \mathrm{FMC}^{+}, \mathrm{CD} 79 \mathrm{~b}^{++}\right.$, slgMD $\left.{ }^{++}\right) ; \mathrm{A}=$ atypical (missing antigen).

${ }^{b} \mathrm{C}$ ells with a B-phenotype: CD $19^{+} / \mathrm{CD} 22^{+} / \mathrm{slg}^{+}$.

${ }^{\circ} \mathrm{C}+=$ presence of a $(11 ; 14)$ in the karyotype; $\mathrm{N}+=$ cyclin $\mathrm{D} 1$ overexpression; $\mathrm{S}+=$ Southern blot rearrangement at MTC locus.

${ }^{d} \mathrm{R}=$ rearrangement (fusion 11q13-14q32); $\mathrm{N}$, no rearrangement.

Configuration A corresponds to a split of the CCND1 probe; B, to the absence of a splice.

nate (FITC) or phycoerythrin (PE) -were used: CD5/IOT1a-FITC and CD19/IOB4-PE (Immunotech); CD23/B6-FITC (Coultronics) and CD22/ leu14-PE (Beckton-Dickinson); FMC7-FITC (Seralab) and CD79b-PE (Immunotech). Surface Ig expression $(\mu, \delta, \gamma, \kappa$, and $\lambda$ chains) was analyzed with FITC-goat F(ab')2 polyclonal antibodies (Kallstad).

\section{Probes}

The 11q13 probe was purchased from Vysis. This probe covers $300 \mathrm{~kb}$, is centered on the CCND1 locus, and contains both $M T C$ and FGF4 loci, but not the $F G F 3$ locus (Fig. 1). The 14q32 probe was selected from a BAC library, using a J1-J6 cDNA probe. Mapping of this probe was performed using PCR with primers specific for the switch regions $S \mu, S \gamma, S \alpha$, and $S \epsilon$, according to Bergsagel et al. (1996). The 11q13 probe was directly labeled with SpectrumOrange. The $14 \mathrm{q} 32$ probe was labeled with biotin in a regular random priming reaction. In order to test the accuracy of this set of probes, we first tested them on two samples with a cytogenetically proved $\mathrm{t}(11 ; 14)$ (patients 7 and 8) (Fig. 2). 


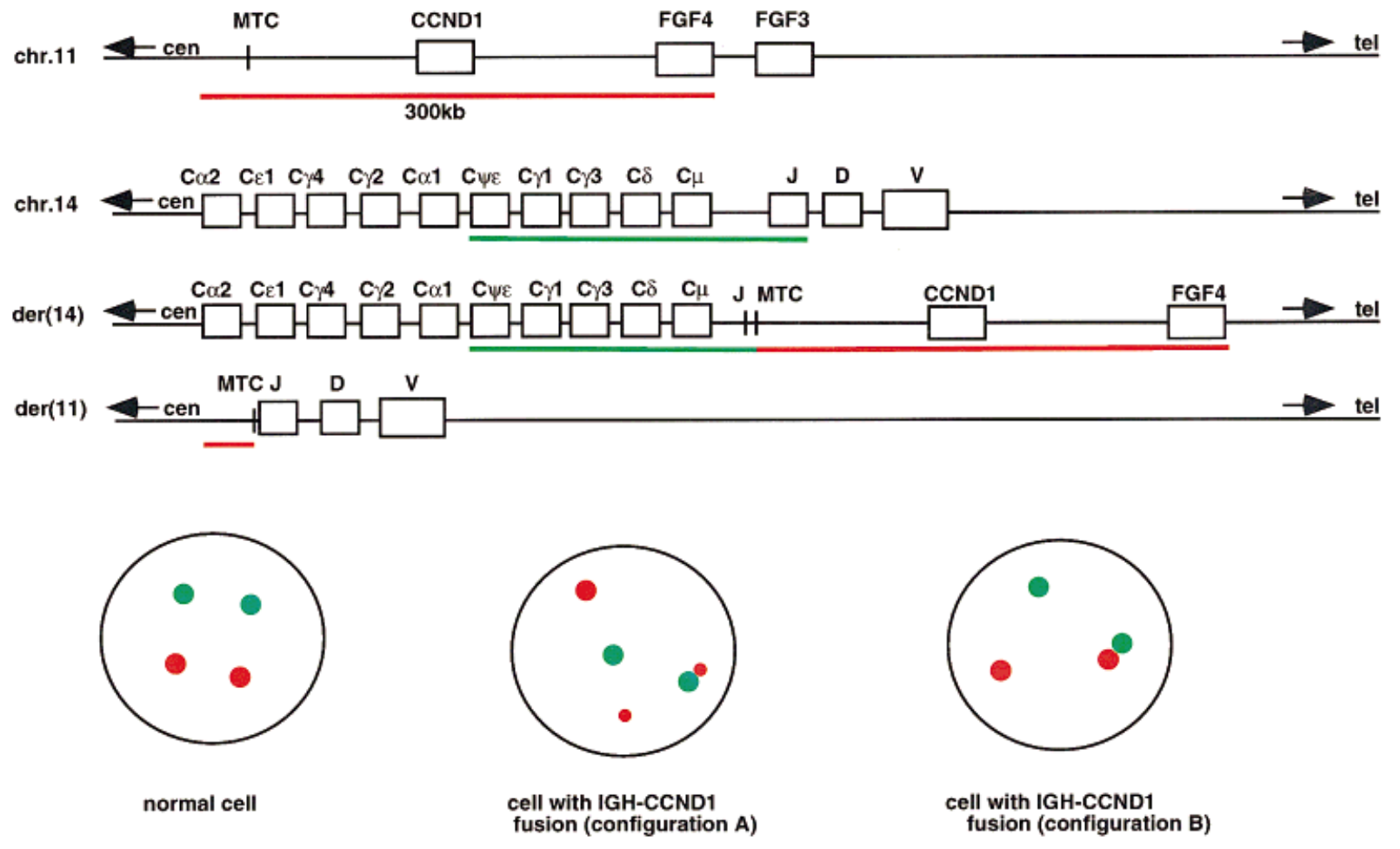

Figure 1. Schematic representation of the probe mapping and configuration on interphase nuclei. The lines and dots represent the 11q13 (red) and the 14q32 (green) probes.
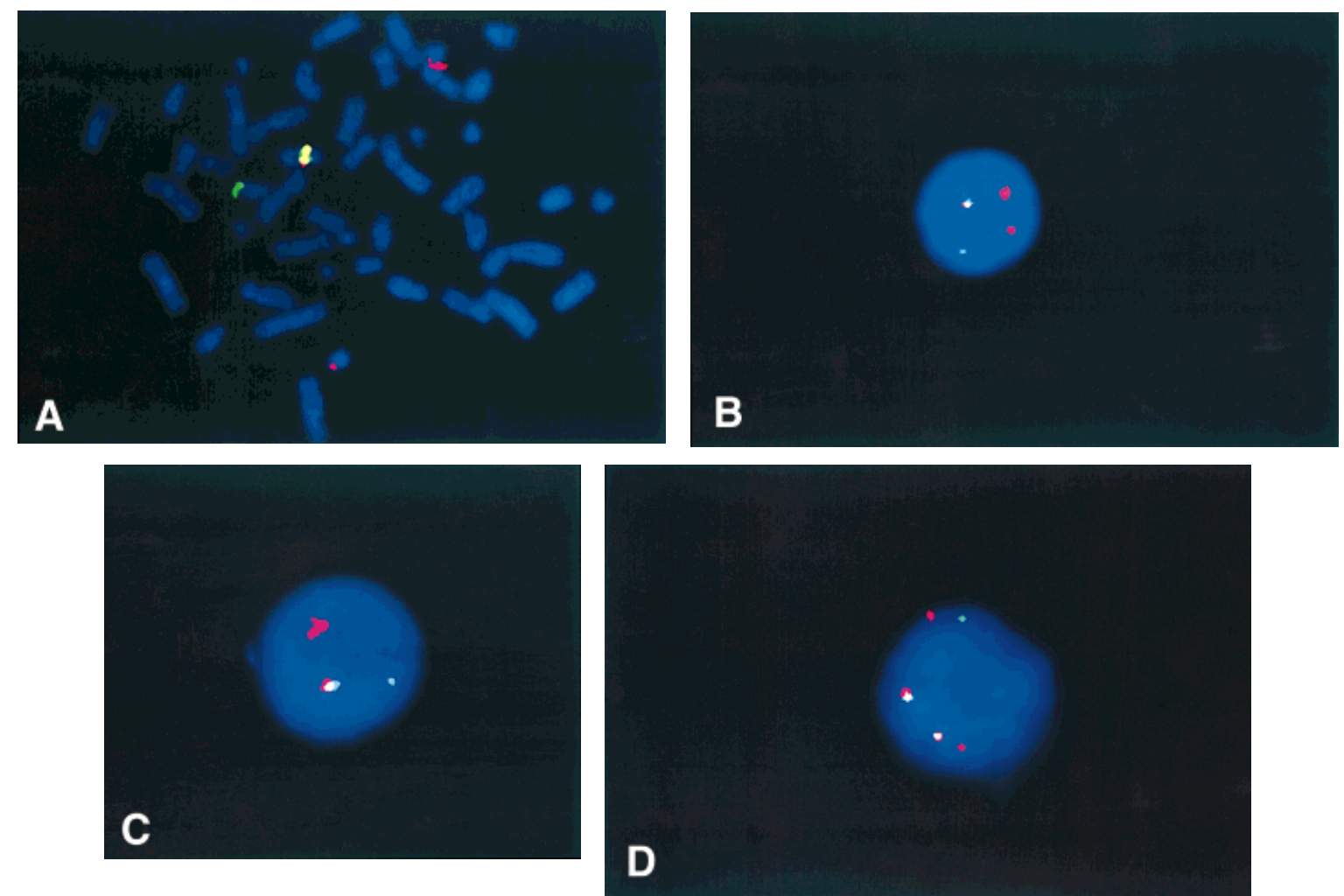

Figure 2. Green signals correspond to the $14 \mathrm{q} 32$ probe, red signals to the $11 q 13$ probe, and yellow signals to the colocalization of the two probes. A: Hybridization on an MCL patient metaphase showing the 11 13 probe splitting and the colocalization of both probes on the der(14). B: A typical cell with a type A IGH-CCND1 fusion. C: A typical cell with a type B IGH-CCNDI fusion. D: An atypical configuration with a probable duplication of the der(14) (patient 30). 


\section{FISH}

Thawed $\mathrm{BM}$ or PB cells were washed in PBS and separated into two samples, one for immunologic analysis and one for FISH analysis. The latter sample was fixed three times in methanol/acetic acid (3/1) and then dropped on slides. Slides were incubated for $30 \mathrm{~min}$ in $2 \times \mathrm{SSC}$ at $37^{\circ} \mathrm{C}$ and then dehydrated. They were then denatured in $70 \%$ formamide at $73^{\circ} \mathrm{C}$ for $90 \mathrm{sec}$ and dehydrated in a cold alcohol series. Two hundred nanograms of the $14 \mathrm{q} 32$ probe was mixed with $1 \mu \mathrm{g}$ of Cot-1 DNA (Gibco, Gaithersburg, MD), denatured for $5 \mathrm{~min}$, and preannealed at $37^{\circ} \mathrm{C}$ for $15-30 \mathrm{~min}$. The $11 \mathrm{q} 13$ probe was denatured for $5 \mathrm{~min}$ and then mixed with the $14 \mathrm{q} 32$ probe. The probes were then applied to slides, covered with a coverslip, and sealed with rubber cement. After overnight hybridization, slides were washed in $2 \times \mathrm{SSC}$ at $73^{\circ} \mathrm{C}$ for $5 \mathrm{~min}$ and then rinsed in $2 \times \mathrm{SSC} / 0.1 \%$ Triton-X100. Detection was performed using FITC-avidin for $10 \mathrm{~min}$ at $37^{\circ} \mathrm{C}$. After a final wash in $2 \times \mathrm{SSC} / 0.1 \%$ Triton$\mathrm{X} 100$, nuclei were counterstained with DAPI.

One hundred to 200 nuclei were then scored using an epifluorescence microscope (Leica) equipped with a triple-band-pass filter. In order to define the sensitivity of this set of probes, we tested them on 10 control patients. For controls, we chose five patients with non-B-cell hematologic malignancies ( 3 acute myeloid leukemia patients and 2 chronic myelocytic leukemia patients in chronic phase) to avoid any $I G H$ rearrangement, and five normal volunteers. We used bone marrow samples from the five patients and peripheral mononuclear cells from the volunteers. Slide preparation and FISH experiments were performed under the same conditions as for MCL samples.

\section{Molecular Analyses}

For 18 patients, RNA was extracted from PB according to Chomczynski and Sacchi (1987). Northern blot analyses were performed with a cDNA cyclin D1 probe, enabling the detection of the two main transcript species of 4.5 and $1.2 \mathrm{~kb}$. For each patient, the RNA amount and quality were controlled by use of a GAPDH-specific probe. We also performed Southern-blot analyses by using an $M T C$ specific probe in six patients.

\section{RESULTS}

\section{Morphologic, Immunophenotypic, and Histopathologic Features}

According to the morphology and immunophenotype of circulating abnormal cells and the histopathologic findings, patients were classified in two groups:
MCL in leukemic phase and atypical CLL with an MCL immunophenotypic profile. Seventeen cases fulfilled the histopathologic criteria for MCL (Harris et al., 1994), including four "blastoid" variants. In this group, circulating abnormal cells (mean= $9 \times 10^{3} / \mu \mathrm{l}$; range, $\left.3-600 \times 10^{3} / \mu \mathrm{l}\right)$ were pleiomorphic lymphocytes with irregular, cleaved, nucleolized nuclei in 14 patients. In addition, blastoid cells were present in two cases histologically classified as blastoid MCL variant. One patient had small monomorphic lymphocytes, which were morphologically indistinguishable from common CLL. Flow studies revealed a typical MCL profile in 15 cases. $\mathrm{IgD}$ expression was absent in one case, and CD5 was negative in another.

In the second group, the initial absolute lymphocyte count was increased in all 21 patients (mean $=$ $21 \times 10^{3} / \mu \mathrm{l}$; range, $\left.7-133 \times 10^{3} / \mu \mathrm{l}\right)$, morphologically classified as mixed cell type CLL in 20 cases and prolymphocytic leukemia (PLL) in one. Histopathologic data were available for six of these cases: three lymphoplasmocytoid lymphomas, two small lymphocytic lymphomas, and one PLL. Circulating abnormal lymphoid cells showed a typical MCL immunophenotypic profile in 17 cases and absence of $\operatorname{IgD}$ expression in four.

\section{Validation of Probes}

Fluorescence in situ hybridization analysis showed bright green and red signals in each experiment (Fig. 2). Analysis of the two samples with $t(11 ; 14)$ revealed one green signal on the normal chromosome 14, one red signal on each chromosome 11 [the normal one and the der(11)], and one yellow signal on the der(14). On controls, in the absence of $I G H-C C N D 1$ rearrangement, two green signals (corresponding to the $14 \mathrm{q} 32$ probe) and two red signals (corresponding to the $11 \mathrm{q} 13$ probe) were detected. Only cells with yellow signals or colocalized signals (without any interval between the two signals) were considered positive for IGH-CGND1 fusion. In controls, we analyzed 200 to 300 nuclei/ control (2,700 nuclei total) and found colocalized signals in $1.8-3.7 \%$ of the cells (mean false positivity $=2.9 \%$ ). Using this set of probes, the cutoff for positivity was fixed at $5.9 \%$ (mean +3 S.D.).

In IGH-CCND1 rearrangements, two different configurations were found (Fig. 1). The first configuration (type A) was one green signal (normal chromosome 14), two red signals [one corresponding to the normal chromosome 11 and one corresponding to the der(11)], and one yellow signal [corresponding to the colocalization of the two probes on the $\operatorname{der}(14)]$. An atypical form of this configuration was found in one patient with two yellow signals instead 
of one (patient 30). The second configuration (type B) was one normal green signal (normal chromosome 14), one red signal (normal chromosome 11), and one yellow signal [der(14)]. The type A configuration corresponds to a breakpoint on chromosome 11 between the MTC and FGF4 loci, therefore splitting the probe. The patient with a variant form probably shared a duplication of the der(14) chromosome. The type B configuration corresponds to a break centromeric to the $M T C$ locus, upstream from the $11 \mathrm{q} 13$ probe.

\section{$\mathbf{t}(11 ; 14)$ in Patients}

We found an $I G H-C G N D 1$ rearrangement in 28 of the 38 patients (Table 2). Among the 28 patients with colocalized signals, 25 displayed the type A configuration and three displayed type B. Comparison of percentages of clonal cells as determined by immunophenotype and percentages of cells with fusion showed an excellent correlation (Table 2). The IGH-CCND1 fusion was found by FISH in all patients with MCL in leukemic phase, whereas only half of atypical CLL patients (11/21) displayed the rearrangement. In this latter group, a $t(11 ; 14)$ was found on both conventional cytogenetic and FISH analyses in one patient histologically classified as lymphoplasmacytic lymphoma.

\section{Molecular Analyses}

PCR experiments with the BAC probe showed the presence of specific PCR products with the $S \mu$, $S \gamma$, and $S \epsilon$ primers, whereas no amplification was obtained with the $\mathrm{S} \alpha$ primers. We concluded that the probe maps within the $\mathrm{JH}, \mathrm{C} \mu, \mathrm{C} \gamma_{4}, \mathrm{C} \gamma_{2}$, and $\mathrm{C}_{2}$ regions (Fig. 1). Among the 18 patients with analyzable RNA, 11 had cyclin D1 overexpression, all of them displaying 11q13/14q32 fusion. Cyclin D1 was not detectable in two patients with typical MCL in leukemic phase, despite an IGH-CGND1 fusion. In contrast, the five patients with atypical CLL and a $\mathrm{t}(11 ; 14)$ using FISH overexpressed cyclin D1. Southern blot experiments using an $M T C$-specific probe showed a rearrangement in three cases, all of them displaying an IGH-CCND1 fusion. Among the three patients without any rearrangement with this probe, two did show an IGH-CCND1 fusion (one patient with each configuration) and one did not show any fusion.

\section{DISCUSSION}

Patients with MCL have in common advanced age, a marked male predominance, generalized lymphadenopathy (including splenomegaly), frequent BM involvement, and a poor outcome with standard therapies (Garcia-Conde and Cabanillas, 1995; Pittaluga et al., 1995; Weisenburger and Armitage, 1996). Even if typical cases are easily recognized from morphologic and immunologic analyses, this may be a difficult challenge for pathologists in atypical cases or when no biopsy specimen is available.

So far, four studies in which FISH was used to detect $\mathrm{t}(11 ; 14)$ have been reported. The first used a dual-color FISH approach with 14q32- and 11q13specific cosmid probes (Monteil et al., 1996). However, this study had a poor sensitivity (23\%). The second study also used a dual-color technique, but with 11q13 probes only (Coignet et al., 1996). Four MCL samples were analyzed and were found to be rearranged with this set of probes. The third published study used a different FISH technique, namely, fiber-FISH using 11q13- and 14q32specific probes (Vaandrager et al., 1996). These investigators found an 11q13-14q32 rearrangement in 19 of 20 MCL. However, this technique is not used routinely. Finally, a recent study using FISH with an 11q13 YAC probe on atypical CLL cases showed that a $\mathrm{t}(11 ; 14)$ was present in $25 \%$ of patients (Cuneo et al., 1997). However, the use of single-color FISH with an 11q13 probe does not allow the differentiation of $11 \mathrm{q} 13$ rearrangements from trisomy 11 . Moreover, $t(11 ; 14)$ with breakpoints centromeric to MTC cannot be detected with this strategy.

In order to detect $t(11 ; 14)$ simply and reliably, we developed an interphase FISH method by using a commercially available large $11 \mathrm{q} 13$ probe and an $I G H$-specific BAC probe. We chose this latter probe because of its large size $(>100 \mathrm{~kb})$, enabling unerring detection on interphase cells (Fig. 2). This set of probes gave clear, bright signals in every case. We found an IGH-CGND1 fusion in 17 of 17 patients with a documented typical MCL. This $100 \%$ positivity demonstrates the high diagnostic sensitivity of this set of probes, which compares favorably with other diagnostic techniques such as cytogenetics, Southern blot, or PCR. In this series, cytogenetics was performed on only three patients (because routine cytogenetics is not performed for lymphomas in our institution). Interestingly, one of these three patients with a normal karyotype displayed a fusion by using FISH, reflecting difficulties to interpret cytogenetic results when no abnormality is found. Southern blotting was performed on six patients, showing a rearrangement in three cases. FISH showed a fusion in these three patients, but also in two others. This discrepancy is explained by the diversity of breakpoints on chromosome 11 . We 
did not perform PCR, but several previous studies showed that only about $50 \%$ of true MCL patients are diagnosed by PCR, because of the wide dispersion of breakpoints on chromosome 11 (de Boer et al., 1993; Rimokh et al., 1994; Luthra et al., 1995).

Moreover, this FISH technique is very easy to perform and gives an accurate assessment in less than $24 \mathrm{hr}$. Interestingly, two patients with a histologically proven MCL did not overexpress cyclin D1, as shown by the negative Northern blot. The RNA amount and quality were carefully assessed. In these two patients, Northern analysis with a control GAPDH probe showed the presence of correct amounts of undegraded RNA. Moreover, FISH analysis showed an IGH-CCND1 fusion of type A configuration; therefore, it did not differ from other MCL cases. These two cases are true $\mathrm{t}(11 ; 14)$-positive MCL patients with absence of CCND1 overexpression. One possible explanation could be an 11q13 breakpoint located downstream of the CCND1 gene, but still splitting the probe.

We also found such a fusion in 11 of 21 patients with an MCL-type immunophenotype, but with absent or discordant histology. These patients have either a leukemic MCL or an atypical CLL with $\mathrm{t}(11 ; 14)$. Atypical CLL probably represents a collection of different entities that should be separated. Genetic abnormalities such as $\mathrm{t}(11 ; 14)$ may be common denominators to individualize new pathological subgroups. Moreover, both MCL and atypical CLL with $\mathrm{t}(11 ; 14)$ have a very poor prognosis and could be grouped together as "mantle cell leukemia," as proposed by Neilson et al. (1996). Thus, the demonstration of the IGH-CCND1 fusion is essential in atypical CLL. Immunophenotyping is clearly not a good technique for this purpose, because half of the cases with a typical MCL phenotype did not share the typical gene fusion. This FISH technique could be performed systematically in patients with CLL and an MCL-type immunophenotype, in order to better characterize this type of B-cell malignancy, as previously proposed (Hernandez et al., 1995; Cuneo et al., 1997).

In conclusion, interphase FISH using this set of large probes allows a rapid and reliable assessment of $t(11 ; 14)$. Such a set of probes would enable large-scale studies for better definition of the incidence and prognostic significance of the $I G H-$ CCND1 fusion in B-cell malignancies. Of special interest is that it would allow for a better nosologic definition of the so-called atypical CLL: the forms with an IGH-CGND1 fusion might be considered as MCL, and the forms without such a fusion could be considered as typical CLL.

\section{REFERENCES}

Bennett JM, Catovsky D, Daniel MT, Flandrin G, Galton DA, Gralnik HR, Sultan C (1989) Proposals for the classification of chronic (mature) B and T lymphoid leukemias: French-AmericanBritish (FAB) cooperative group. J Clin Pathol 42:567-584.

Bergsagel PL, Chesi M, Nardini E, Brents LA, Kirby SL, Kuehl WM (1996) Promiscuous translocations into immunoglobulin heavy chain switch regions in multiple myeloma. Proc Natl Acad Sci USA 93:13931-13936.

Chomczynski P, Sacchi N (1987) Single-step method of RNA isolation by acid guanidium thiocyanate-phenol-chloroform extraction. Anal Biochem 162:156-159.

Coiffier B, Hiddemann W, Stein H (1995) Mantle cell lymphoma: A therapeutic dilemma. Ann Oncol 6:208-211.

Coignet LJA, Schuuring E, Kibbelar RE, Raap TK, Kleiverda KK, Bertheas MF, Wiegant J, Beverstock G, Kluin PM (1996) Detection of $11 \mathrm{q} 13$ rearrangements in hematologic neoplasias by doublecolor fluorescence in situ hybridization. Blood 87:1512-1519.

Cuneo A, Bigoni R, Negrini M, Bullrich F, Veronese ML, Roberti MG, Bardi A, Rigolin GM, Cavazzini P, Croce CM, Castoldi G (1997) Cytogenetic and interphase cytogenetic characterization of atypical chronic lymphocytic leukemia carrying BCL1 translocation. Cancer Res 57:1144-1150.

de Boer CJ, Loyson S, Kluin PM, Kluin-Nelemans HC, Schuuring E, van Krieken JHJM (1993) Multiple breakpoints within the BCL-1 locus in B-cell lymphoma: Rearrangements of the cylin D1 gene. Cancer Res 53:4148-4152.

de Boer CJ, van Krieken JHJM, Kluin-Nelemans HC, Kluin PM, Schuuring E (1995a) Cyclin D1 messenger RNA overexpression as a marker for mantle cell lymphoma. Oncogene 10:1833-1840.

de Boer CJ, Schuuring E, Dreef E, Peters G, Bartek J, Kluin PM, van Krieken JHJM (1995b) Cyclin D1 protein analysis in the diagnosis of mantle cell lymphoma. Blood 86:2715-2723.

Fisher RI, Dahlberg S, Nathwani BN, Banks PM, Miller TP, Grogan TM (1995) A clinical analysis of two indolent lymphoma entities: Mantle cell lymphoma and marginal zone lymphoma (including mucosa-asociated lymphoid tissue and monocytoid B cell categories)—A Southwest Oncology Group study. Blood 85:1075-1082.

Garand R, Robillard N (1996) Immunophenotypic characterization of acute leukemias and chronic lymphoproliferative disorders: Practical recommendations and classifications. Hematol Cell Ther 38:471-486.

Garcia-Conde J, Cabanillas F (1995) Mantle cell lymphoma: A new lymphoproliferative entity with definite histopathological patterns, clinical characteristics and prognostic factors, and an investigational therapeutic approach. Ann Oncol 6:305-308.

Harris NL, Jaffe ES, Stein H, Banks PM, Chan JKC, Cleary ML, Delsol G, De Wolf-Peeters C, Falini B, Gatter KC, Grogan TM, Isaacson PG, Knowles DM, Mason DY, Muller-Hermelink HK, Pileri SA, Piris MA, Ralfkiaer E, Warnke RA (1994) A revised European-American classification of lymphoid neoplasms: A proposal from the international lymphoma study group. Blood 84:13611392.

Hernandez JM, Mecucci C, Criel A, Meeus P, Michaux L, Van Hoof A, Verhoef G, Louwagie A, Scheiff JM, Michaux JL, Booghaerts M, Vandenberghe H (1995) Cytogenetic analysis of B-cell chronic lymphoid leukemias classified according to morphologic and immunophenotypic (FAB) criteria. Leukemia 9:2140-2146.

Lardelli P, Bookman MA, Sundeen J, Longo DL, Jaffe ES (1990) Lymphocytic lymphoma of intermediate differentiation: Morphologic and immunophenotypic spectrum and clinical correlations. Am J Surg Pathol 14:752-763.

Leroux D, Le Marc'hadour F, Gressin R, Jacob MC, Keddari E, Monteil M, Caillot P, Jalbert P, Sotto JJ (1991) Non-Hodgkin's lymphomas with $\mathrm{t}(11 ; 14)(\mathrm{q} 13 ; \mathrm{q} 32)$ : A subset of mantle/intermediate lymphocytic lymphoma? Br J Haematol 77:346-353.

Luthra R, Hai S, Pugh WC (1995) Polymerase chain reaction detection of the $t(11 ; 14)$ translocation involving the bcl-1 major translocation cluster in mantle cell lymphoma. Diag Mol Pathol $4: 4-7$.

Matutes E, Owusu-Ankomah K, Morilla R, Garcia-Marco J, Houlihan A, Que TH, Catovsky D (1994) The immunological profile of B-cell disorders and proposal of a scoring system for the diagnosis of CLL. Leukemia 8:1640-1646.

Monteil M, Callanan M, Dascalescu C, Sotto JJ, Leroux D (1996) Molecular diagnosis of $\mathrm{t}(11 ; 14)$ in mantle cell lymphoma using two-colour interphase fluorescence in situ hybridization. Br J Haematol 1996:656-660. 
Neilson JR, Fegan CD, Milligan DW (1996) Mantle cell leukemia? Br J Haematol 93:494-495.

Pittaluga S, Wlodarska I, Stul MS, Thomas J, Verhoef G, Cassiman JJ, van den Berghe H, de Wolf-Peeters C (1995) Mantle cell lymphoma: A clinicopathologic study of 55 cases. Histopathology 26:17-24.

Rimokh R, Berger F, Delsol G, Chanin C, Bertheas MF, French M, Garoscio M, Felman P, Coiffier B, Bryon PA, Rochet M, Gentilhomme O, Germain D, Magaud JP (1993) Rearrangement and overexpression of the bcl-1/PRAD-1 gene in intermediate lymphocytic lymphomas and in $\mathrm{t}(11 \mathrm{q} 13)$-bearing leukemias. Blood 81: 3063-3067.

Rimokh R, Berger F, Delsol G, Digonnet I, Rouault JP, Tigaud JD, Gadoux M, Coiffier B, Bryon PA, Magaud JP (1994) Detection of the chromosomal translocation $\mathrm{t}(11 ; 14)$ by polymerase chain reaction in mantle cell lymphomas. Blood 83:1871-1875.

Segal GH, Masih AS, Fox AC, Jorgensen T, Scott M, Braylan RC (1995) CD5-expressing B-cell non-Hodgkin's lymphomas with bcl-1 gene rearrangement have a relatively homogeneous immunophenotype and are associated with an overall poor prognosis. Blood 85:1570-1579.

Stewart DA, Vose JM, Weisenburger DD, Anderson JR, Ruby EI, Bast MA, Bierman PJ, Kessinger A, Armitage JO (1995) The role of high-dose therapy and autologous hematopoietic stem cell transplantation for mantle cell lymphoma. Ann Oncol 6:263-266.
Teodorovic I, Pittaluga S, Kluin-Nelemans JC, Meerwaldt JH, Hagenbeek A, van Glabbeke M, Somers R, Bijnen L, Noordijk EM, De Wolfe-Peeters C (1995) Efficacy of four different regimens in 64 mantle-cell lymphoma cases: Clinicopathologic com parison with 498 other non-Hogkin's lymphoma subtypes. J Clin Oncol 13:1819-1828.

Uchimaru K, Taniguchi T, Yoshikawa M, Asano S, Arnold A, Fujita T, Motokura T (1997) Detection of cyclin D1 (bcl-1, PRAD1) overexpression by a simple competitive reverse transcriptionpolymerase chain reaction assay in $\mathrm{t}(11 ; 14)(\mathrm{q} 13 ; \mathrm{q} 32)$-bearing $\mathrm{B}$-cell malignancies and/or mantle cell lymphoma. Blood 89:965-974.

Vaandrager JW, Schuuring E, Zwikstra E, de Boer CJ, Kleiverda KK, van Krieken JHJM, Kluin-Nelemans HC, van Ommen GJB, Raap AK, Kluin PM (1996) Direct visualization of dispersed 11q13 chromosomal translocations in mantle cell lymphoma by muticolor DNA fiber fluorescence in situ hybridization. Blood 88:11771182.

Vandenberghe E, de Wolf-Peeters C, Wlodarska I, Stul M, Louwagie A, Verhoef G, Thomas J, Criel A, Cassiman JJ, Mecucci C, van den Berghe H (1992) Chromosome 11q rearrangements in B nonHodgkin's lymphoma. Br J Haematol 81:212-217.

Weisenburger DD, Armitage JO (1996) Mantle cell lymphoma: an entity comes of age. Blood 87:4483-4494.

Zucca E, Roggero E, Pinotti G, Pedrinis E, Cappella C, Venco A, Cavalli F (1995) Patterns of survival in mantle cell lymphoma. Ann Oncol 6:257-262. 